\section{Does CCR5 gene- $\Delta 32$ deletion protect C.trachomatis infected Indian women from tubal pathology?}

\author{
Jayanti Mania-Pramanik, ${ }^{1}$ \\ Shilpa C. Kerkar, ${ }^{1}$ Anjali Vallabhadas, ${ }^{1}$ \\ Pratibha B. Mehta, ${ }^{1}$ Vinita Salvi ${ }^{2}$ \\ 1Department of Infectious Diseases \\ Biology, National Institute for Research \\ in Reproductive Health (Indian Council \\ of Medical Research), Mumbai; \\ ${ }^{2}$ Seth G. S. Medical College and KEM \\ Hospital, Mumbai, India
}

\section{Abstract}

Deletion in chemokine receptor CCR5 gene is reported to prevent development of tubal pathology among Dutch Caucasian $C$. trachomatis infected women. Hence, a pilot study was undertaken, to evaluate the involvement of CCR5 gene in tubal pathology among Indian women with or without Chlamydia infection. Three hundred women with or without Chlamydia infection and with different reproductive manifestations were screened for CCR5 gene using a standardized PCR. Only 6 C. trachomatis infected women without tubal block had heterozygous deletion for this gene. The rest had wild type CCR5 gene, that includes fertile women infected and non infected; infertile women infected and non infected with and without tubal block as well as infected women with history of recurrent spontaneous abortions. The study indicates no role of heterozygous CCR5 $\Delta 32$ gene deletion in prevention of tubal pathology in Chlamydia infected Indian women. Only 2\% heterozygous deletion in CCR5 gene is observed in the studied population.

\section{Introduction}

Several studies in different populations have reported the role of mutant allele of the $\beta$ chemokine receptor gene CCR5 bearing a 32 base pair deletion ( $\triangle$ CCR5) in prevention of HIV-1 transmission. Homozygote's for this mutation are resistant to HIV-1 infection, even after repeated high-risk exposures. ${ }^{1-4}$ Among Caucasians, approximately $<1 \%$ has homozygous deletion, whereas $13-20 \%$ has heterozygous deletion. ${ }^{5}$ The total number of Indian sample surveyed for such deletion was small. A screening of 100 normal Indian individuals revealed a single $(<1 \%)$ heterozygous dele- tion. ${ }^{6}$ Another study with 1436 individual belonging to 40 ethnic groups from North-East, East, South, Central and North India revealed heterozygous deletion ranging from 1.47$4.69 \%$, while the maximum frequency of $5.36 \%$ was observed among Muslims of Northern India. ${ }^{7}$ A study from North India that included 119 healthy individuals and 180 HIV-1 seropositive subjects revealed no mutation in this allele. ${ }^{8}$ No study on this gene deletion has been reported from Western India and particularly from Mumbai where the HIV infection rate $(7.69 \%)$ is high. ${ }^{9}$ Hence, distribution of this mutation need more studies. Significance of CCR5 mutation is studied extensively in HIV transmission but isolated studies have reported its role in Chlamydia trachomatis (C. trachomatis) infection. ${ }^{10-12}$

C. trachomatis infection is the most common cause of pelvic inflammatory disease (PID) and tubal factor infertility (TFI) world wide. ${ }^{13}$ Current observation shows that only a certain fraction of infected women develop upper genital tract infection and only a subfraction of them develop further complications. A study carried out in Caucasian population has reported the role of CCR5 in Chlamydia related pathology. ${ }^{10}$ This group has reported that a deficiency of specific anti chlamydial Th1 response leads to delayed clearance of genital chlamydial infection. However, CCR5 Knock Out mice were protected from the complication of the genital infections relating to infertility. In addition, they also reported that C. trachomatis exposed women with CCR5 gene $\Delta 32$ deletion appear to be protected from tubal pathology as well, suggesting a crucial role for CCR5 related specific Th1 and inflammatory responses in the pathogenesis of TFI. There is no report on the association of this Chemokine receptor CCR5 on the development of TFI in the Indian population. Another study revealed that both CXCR3 and CCR5 are pivotal for T-lymphocyte access to the genital tract during $C$. trachomatis infection, T cells lacking both receptors are completely non protective. ${ }^{11}$ Study also reported that patients with heterozygous $\Delta 32$ deletion had 5 to 10 fold higher bacterial burden than with wild-type gene. ${ }^{12}$ These reports have suggested association of CCR5 gene in $C$. trachomatis infection as well as in development of complications. However, these findings need to be correlated with other ethnic groups for better understanding of the role of CCR5 gene $\Delta 32$ deletion. Hence, a pilot study was carried out to establish if CCR5 is associated with $C$. trachomatis infection as well as development of Chlamydia related TFI in our population.
Correspondence: Jayanti Mania-Pramanik, Department of Infectious Diseases Biology National Institute for Research in Reproductive Health, (Indian Council of Medical Research), J M Street, Parel, Mumbai 400 012, India.

Tel. +91.022.24192039 - Fax +91.022.24139412. E-mail: jayantimania@rediffmail.com

Key words: CCR5, Chlamydia, tubal infertility.

Acknowledgments: this research was supported by Ad-Hoc Research Grant (5/7/129/05/RHN) from the Indian Council of Medical Research, India.

Contributions: JMP conceived the idea, wrote the manuscript; SCK sample collection ,laboratory analysis; AV laboratory analysis, data compilation; PBM subject enrollment, follow up; VS subject selection, treatment, management, manuscript editing.

Conflict of interest: the authors report no conflicts of interest.

Received for publication: 22 May 2011.

Revision received: 16 June 2011.

Accepted for publication: 2 July 2011.

This work is licensed under a Creative Commons Attribution NonCommercial 3.0 License (CC BYNC 3.0).

@CCopyright J. Mania-Pramanik et al., 2011

Licensee PAGEPress, Italy

Microbiology Research 2011; 3:e5

doi:10.4081/mr.2011.e5

\section{Materials and Methods}

\section{Subjects}

Women attending the Obstetrics and Gynecology Out Patients Department (OPD) of Seth Gordhandas Sunderdas Medical College and King Edward Memorial (KEM) Hospital, Mumbai, India for reproductive health related issues were enrolled. The group comprised of women with history of recurrent spontaneous abortion (RSA), infertility, as well as those who had no symptom and sign of any infection (controls) but came for family planning advice. Ethics Committees of the institute as well as of KEM Hospital has approved the study. Each subject was informed about the study as well as about $C$. trachomatis and its consequences on reproductive health. Informed written consent was obtained from all the subjects before enrollment. Detailed history was taken from the case papers and also by interviewing the subject and their spouse if available. Clinical examination was done by the clinician and the observations were recorded. Tubal pathology was defined as extensive periadnexal adhesions and/or distal occlusions of one or both tubes as recorded laparoscopically by the clinician. 


\section{Collection of specimen}

Endocervical swabs were collected using sterile cotton swab (Hi Media), for diagnosis of C. trachomatis. Two swabs in $0.1 \mathrm{M}$ phosphate buffered saline (PBS, pH 7.5) for analysis and one swab in a dry collection vial was kept for quality control analysis. Five milliliters of venous blood was drawn, of which $2 \mathrm{~mL}$ was without any anti coagulant for serum collection for diagnosis of past $C$. trachomatis infection (C. trachomatis specific IgG) and $3 \mathrm{~mL}$ in EDTA for DNA extraction for CCR5 gene $\Delta 32$ deletion analysis.

\section{Laboratory diagnosis \\ of C. trachomatis}

DNA was extracted from the swab samples collected in 0.1M PBS using a rapid non-enzymatic method. ${ }^{14}$ Polymerase Chain Reaction (PCR) amplification of in-house-globin gene was carried out to identify sampling errors and to monitor the absence of PCR inhibitors in the extracted genomic DNA. PCR was performed on extracted DNA using a primer pair selected from the conserved region of the Major Outer Membrane Protein (MOMP) gene of $C$. trachomatis ${ }^{15}$ following a standardized PCR program. ${ }^{16}$ This primer pair amplifies an 180bp DNA fragment, which is common to all serotypes of $C$. trachomatis. The amplified 180bp PCR products were immediately frozen for further analysis or electrophoresis was carried out on $2 \%$ agarose gel containing Ethidium bromide and observed under a UV transilluminator and the results were documented. Further confirmation of this detection was done by southern blotting with transfer of DNA PCR products to nylon membrane, which was then processed for hybridization using a $C$. trachomatis specific probe. PCR dig-labeling reagent (Roche diagnostics $\mathrm{G}_{\mathrm{mb}} \mathrm{H}$, Mannheim, Germany) was used to synthesize probe. Immunodetection was carried out using dig-luminescence detection reagents (Roche diagnostics $\mathrm{GmbH}$, Mannheim, Germany). Quality of these PCR results were further assessed using the commercially available kit from Roche diagnostics (AMPLICOR Chlamydia trachomatis/Neisseria gonorrhoeae test). For this all the DNA PCR positive samples and randomly selected negative samples were evaluated using the swabs kept in dry collection vials. Commercially available enzyme-linked immunosorbent assay (ELISA) for $C$. trachomatis specific IgG antibody detection (NovaTec Immunodiagnostica, $\mathrm{G}_{\mathrm{MB}} \mathrm{H}$ ) was carried out as per the instruction manual. In brief, Microtitre wells precoated with $C$. trachomatis antigens were incubated with serum specimen at a 1:100 dilution so that any corresponding antibodies if present in the serum would bind to antigen to form complexes. After washing the wells to remove all unbound sample material, horseradish peroxidase (HRP) labeled antihuman IgG conjugate was added that binds to captured Chlamydia specific antibodies. The immune complex formed by the bound conjugate was visualized by adding Tetramethylbenzidine (TMB) substrate, which gives a blue reaction product. After terminating the reaction using stop solution (sulphuric acid, $0.2 \mathrm{~mol} / \mathrm{L}$ ), the absorbance of the end product, which is yellow in color, was read at $450 \mathrm{~nm}$ using an ELISA plate reader (Quant, Bio-Tek Instruments, Inc.). The intensity of this product is proportional to the amount of Chlamydia-specific IgG antibodies in the specimen. The specimens with O.D. higher than the cut off value $(0.250-0.900)$ were considered positive for Chlamydia specific antibodies and used as an indicator of past Chlamydia infection.

\section{CCR5 gene $\triangle 32$ deletion PCR}

Genomic DNA was extracted from $3 \mathrm{~mL}$ blood in EDTA using a rapid non-enzymatic method with some modifications. ${ }^{14}$ The human CCR5 gene $\Delta 32$ deletion was determined by PCR using sense primer CCR 5-d32 S: 5'-CAAAAAGAAGGTCTTCATTACACC-3' and antisense primer CCR 5-d32 AS: 5'-CCTGTGCCTCTTCTTCTCATTTCG3 '. ${ }^{10}$ The following PCR conditions was followed: 5 min at $94^{\circ} \mathrm{C}$, followed by 35 cycles of $60 \mathrm{sec}$ at $94^{\circ} \mathrm{C}, 60 \mathrm{sec}$ at $55^{\circ} \mathrm{C}$, and $60 \mathrm{sec}$ at $72^{\circ} \mathrm{C}$, followed by final extension of $7 \mathrm{~min}$ at $72^{\circ} \mathrm{C}$ with final storage at $4^{\circ} \mathrm{C}$. The PCR product was electrophoresed on $3 \%$ agarose to identify the following 3 fragments: Wild type (WT) CCR5 gene with 189bp product, homozygote CCR5 mutant gene with 157bp, and the heterozygote CCR5 gene product with both $189 \mathrm{bp}+157 \mathrm{bp}$ DNA. For further confirmation or resolution, the PCR product was run on 12\% Polyacrylamide Gel Electrophoresis (PAGE).

Table 1. Frequency of CCR5 32 gene deletion in different group of women with or without Chlamydia infection.

\begin{tabular}{|c|c|c|c|c|}
\hline \multirow{2}{*}{$\begin{array}{l}\text { Subjects } \\
(\mathrm{n}=300)\end{array}$} & \multicolumn{2}{|c|}{ Chlamydia trachomatis } & \multicolumn{2}{|c|}{ CCR5 gene } \\
\hline & Result & Type of test & Wild type & Heterozygous \\
\hline \multirow{5}{*}{$\begin{array}{l}\text { Fertile } \\
(\mathrm{n}=126)\end{array}$} & Negative & - & 84 & - \\
\hline & Positive & & & \\
\hline & $(n=42)$ & DNA-PCR & 18 & - \\
\hline & & AbTest-ELISA & 12 & - \\
\hline & & Both & 12 & - \\
\hline \multirow[t]{4}{*}{$\begin{array}{l}\text { Infertile } \\
\text { (No tubalblock, } n=60 \text { ) }\end{array}$} & $\begin{array}{c}\text { Negative } \\
(\mathrm{n}=30)\end{array}$ & - & 30 & - \\
\hline & Positive & DNA-PCR & 21 & 3 \\
\hline & $(\mathrm{n}=30)$ & AbTest-ELISA & 6 & - \\
\hline & & Both & 0 & - \\
\hline \multirow[t]{4}{*}{$\begin{array}{l}\text { Infertile } \\
\text { (Tubal block, } n=81 \text { ) }\end{array}$} & $\begin{array}{c}\text { Negative } \\
(\mathrm{n}=45)\end{array}$ & - & 45 & - \\
\hline & Positive & DNA-PCR & 15 & - \\
\hline & $(\mathrm{n}=36)$ & AbTest-ELISA & 15 & - \\
\hline & & Both & 6 & - \\
\hline \multirow{3}{*}{$\begin{array}{l}\text { RSA } \\
(\mathrm{n}=33)\end{array}$} & Positive & DNA-PCR & 24 & 3 \\
\hline & $(n=33)$ & AbTest-ELISA & 6 & - \\
\hline & & Both & - & - \\
\hline
\end{tabular}

DNA-PCR, detection by PCR using DNA samples; Ab Test-ELISA, antibody test using ELISA method.
The study included 300 selected women of which 141 had $C$. trachomatis infection. Infection in each woman was confirmed by southern blotting using $C$. trachomatis specific probe as well as by quality control assay. These women were with different clinical history like, infertility $(\mathrm{n}=141)$ with and without tubal block, recurrent spontaneous abortion $(\mathrm{n}=33)$ and age matched 126 healthy women. They belonged to an age group of $28 \pm 5$ years. Their clinical history, $C$. trachomatis infection status and CCR5 gene amplification result is presented in Table 1 . There were only 3 cases (10\%, 3/30) with a heterozygous CCR5 mutant gene among the Chlamydia infected infertile women without any tubal block. All the infected women with tubal block had WT CCR5 gene. Among women with Chlamydia infection and history of recurrent spontaneous abortion, 3out of 33 (9.1\%) had a heterozygous mutant genotype. Therefore, only 6 of the $300(2 \%)$ enrolled subjects had heterozygous mutant CCR5 genotype. The amplification product of wild type gene (189 bp) as well as the heterozygote deletion of CCR5 gene (189 bp and $157 \mathrm{bp}$ ) is represented in Figure 1. Further analysis of socioeconomic data of these population revealed that the 6 women with heterozygous mutant CCR5 genotype belonged to Muslim community. In the study, 12 women were from this religious community. 


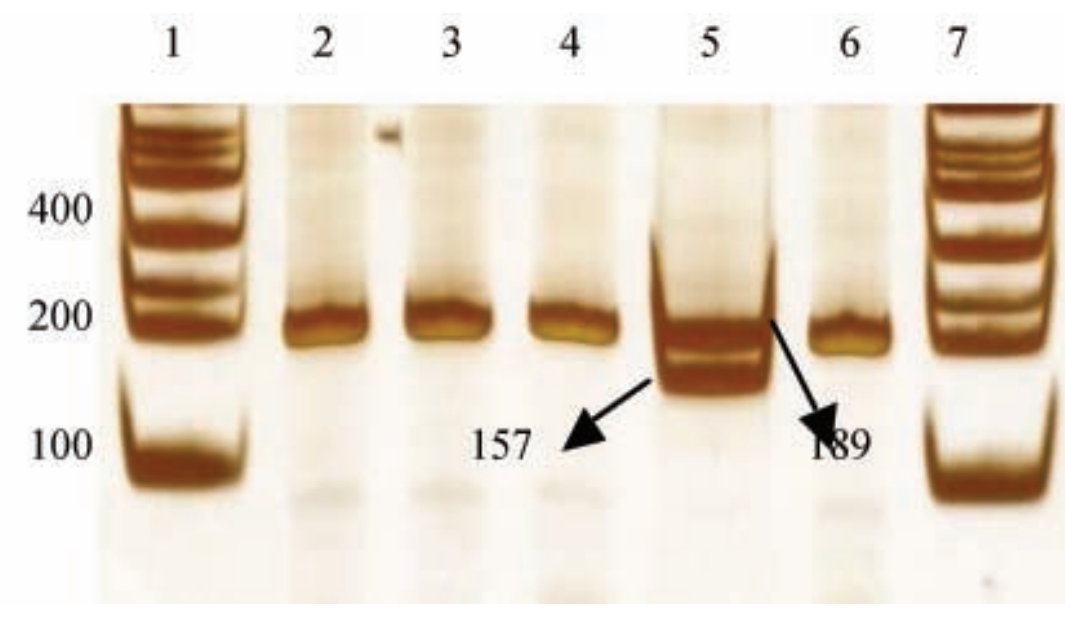

Figure 1. Genotypes of CCR 5 gene: Wild type and Heterozygous genotype, 12\% PAGE. Lane 1 \& 7: 100 bp DNA ladder. Lane 2-4 \& 6: WT CCR5 gene (189 bp). Lane 5: Heterozygous CCR5 gene (189 bp + $157 \mathrm{bp})$

\section{Discussion}

In our western Indian population, we found only $2 \%$ ( 6 of 300 ) of the studied subjects with heterozygous CCR5 gene $\Delta 32$ deletions, all of whom belonged to the Muslim community. Similar observations, a maximum frequency (5.36\%) of the CCR5 $\Delta 32$ heterozygous deletion is reported among this religious community in Indian population by others in a HIV study. ${ }^{7}$ The present study revealed only 3 of 30 (10\%) Chlamydia infected subject with infertility without tubal block had a heterozygous deletion for CCR5 gene, all the rest (90\%, 27 of 30 ) infected women had wild type CCR5 gene but are free of tubal pathology. Other 30 Chlamydia negative women with infertility but without tubal block also had WT CCR5 gene. None of the Chlamydia positive women with tubal block had CCR5 $\Delta 32$ gene deletions. This indicates that CCR5 $\Delta 32$ gene deletions might not be associated with prevention of tubal pathology, specifically among the Indian women, though the group with heterozygous deletion might be originally belong to migrated Caucasian, as per history of India. Study in Dutch Caucasian women reported a frequency of $14 \%$ to $21 \%$ CCR5 $\Delta 32$ gene deletion among the population itself, which was mostly heterozygous. The homozygous deletion was within $1 \% .{ }^{10}$ They reported that among patients with anti-chlamydia IgG responses, tubal pathology correlated with a low incidence of CCR5 $\triangle 32$ deletion (7\%), while women without tubal pathology had higher incidence of the CCR5 $\Delta 32$ deletion (31\%), which was a mixture of heterozygous and homozygous deletion. ${ }^{10}$ The occurrence of CCR5 $\Delta 32$ deletion in these subjects without tubal pathology might be a chance factor, as the frequency of these deletion is higher in these Caucasians.
This is because, rest $69 \%$ of their studied population, were also with $C$. trachomatis infection and without this deletion did not develop tubal block. Similarly among the women with tubal pathology, 7\% had this deletion, again a mixture of homozygous and heterozygous deletion while rest had wild type gene. ${ }^{10}$ In the present study, women with tubal factor pathology leading to infertility with or without Chlamydia infection had WT CCR5 gene. Even women with and without $C$. trachomatis infection both with proven fertility and with history of recurrent spontaneous abortion (except 3), all had WT CCR5 gene, indicating no role of WT CCR5 gene in development of tubal pathology. It maybe noted that none of the women with tubal block had a gene deletion, while 6 of the 63 without tubal block had heterozygous deletion and were free of tubal pathology. But the rest 57 without any deletion were also free of TFI. In the present study, we have not analyzed the bacterial load as has been reported earlier that wild-type gene may influence the Chlamydia bacterial load. ${ }^{12}$ Though, we have not studied the CXCR3 gene, our observation did not correlate association of CCR5 wild type gene with protection against $C$. trachomatis infection as reported earlier. ${ }^{11}$ Hence, some other factors and not CCR $5 \Delta 32$ gene deletion in isolation may be associated with protection from $C$. trachomatis infection as well as from tubal pathology in infected women.

\section{References}

1. Liu R, Paxton WA, Choe S, et al. Homozygous defect in HIV-1 co-receptor accounts for resistance of some multiplyexposed individuals to HIV-1 infection. Cell 1996;86:367-77.
2. Samson M, Libert F, Doranz BJ, et al. Resistance to HIV-1 infection in Caucasian individuals bearing mutant alleles of the CCR5 chemokine receptor gene. Nature 1996;382:722-25.

3. Dean M, Carrington M, Winkler C, et al. Genetic restriction of HIV-1 infection and progression to AIDS by a deletion allele of the CCR5 structural gene. Science 1996; 273:1856-62.

4. Paxton AW, Martin SR, Tse D, et al. Relative resistance to HIV-1 infection of CD4 lymphocytes from persons who remain uninfected despite multiple high-risk sexual exposures. Nature Med 1996;2: 412-7.

5. Biti R, French R, Young J, et al. HIV-1 infection in an individual homozygous for the CCR5 deletion allele. Nature Med 1997;3: 252-3.

6. Husain S, Goila R, Shahi S, Banerjee A. First report of a healthy Indian heterozygous for delta 32 mutant of HIV-1 co-receptor- CCR5 gene. Gene 1998;207:141-7.

7. Majumder PP, Dey B. Absence of the HIV-1 protective delta CCR5 allele in most ethnic populations of India. Eur $\mathrm{J}$ Hum Genet 2001;9:794-6.

8. Kaur G, Singh P, Rapthap CC, et al. Polymorphism in the CCR5 gene promoter and HIV-1 infection in North Indians. Hum Immunol 2007;68:454-61.

9. Articles. Times of India. indiatimes.com /2010-03-07/Mumbai/

10. Barr EL, Ouburg S, Igietseme JU, et al. Host inflammatory response and development of complications of Chlamydia trachomatis genital infection in CCR5-deficient mice and subfertile women with the CCR5 $\Delta 32$ gene deletion. J Microbiol Immunol Infect 2005;38:244-54.

11. Olive AJ, Gondek DC, Starnbach MN. CXCR3 and CCR5 are both required for T cell-mediated protection against $\mathrm{C}$. trachomatis infection in the murine genital mucosa. Mucosal Immunol 2011;4:208-16.

12. Gerard HC, Stanich JA, Oszust CE, et al. Functional CCR5 receptor protects patients with arthritis from high synovial burden of infecting Chlamydia trachomatis. Am J Med Sci 2010;340:448-51.

13. Schachter J. Chlamydia infections (in three parts). N Engl J Med 1978;298:428-35, 490$95,540-49$.

14. Lahiri DK, Nurnberger IN, Jr. A rapid nonenzymatic method for the preparation of HMW DNA from blood for RFLP studies. Nuc Acid 1991;9:5444.

15. Stephens RS, Sanchez-Pescador R, Wagar EA, et al. Diversity of Chlamydia trachomatis major outer membrane protein genes. $\mathrm{J}$ Bacteriol 1987;169:3879-85.

16. Mania-Pramanik J, Potdar S, Kerkar S. Diagnosis of Chlamydia trachomatis infection. J Clin Lab Anal 2006;20:8-14. 